\title{
Nomenclature and Functions of Corporate Communication Units of Nigerian Universities: A Comparative Examination
}

\author{
EKANEM THELMA \\ Department of Mass Communication, Covenant University KM 10, Idiroko Road, Canaan Land, Ota, \\ NIGERIA \\ ROTIMI OLATUNJI \\ Office of the Dean, School of Communication, Lagos State University, Ojo Campus, Lagos, NIGERIA
}

\section{LANRE AMODU}

Department of Mass Communication, Covenant University KM 10, Idiroko Road, Canaan Land, Ota,

\section{OSCAR ODIBOH}

Department of Mass Communication, Covenant University KM 10, Idiroko Road, Canaan Land, Ota,

\author{
DAVID IMHONOPI \\ Department of Sociology, Covenant University \\ KM 10, Idiroko Road, Canaan Land, Ota, NIGERIA
}

\begin{abstract}
Communication is an essential process in universities. Corporate objectives, goals, relationships and control are ensured or jeopardised by the communication network put in place by university management. The name of an organisational communication unit has strategic implications, and its functions distinguish it from other units within the university. The paper uncovers various labels of universities' corporate communication units. It shows the functions of these units; and how the labels determine their functions. In-depth interview was used to gather data from communication officers of six selected universities in southwest, Nigeria. While the descriptive survey helped to generate data from other employees of corporate communication units as well as faculty members of mass communication departments of the six selected universities. Findings show that $41.4 \%$ of the respondents did not know the name of the corporate communication unit of their universities. Communication officers affirmed that the unit carried out several functions. A revelation is that, in some cases, the name of a communication unit could influence how the Unit functions. The study concluded that there was need for universities to have a standardised document on corporate communication unit naming, structure and operations. It was recommended that universities could adopt the Directorate of Public Relations as the name of their communication unit for uniformity and consistency.
\end{abstract}

Key-words: Corporate communication, Communication Units, Functions, Nomenclature

Received: March 25, 2020. Revised: November 20, 2020. Accepted: November 23, 2020.

Published: November 23, 2020. 


\section{Introduction}

Communication is a significant aspect of existence. It serves as the medium through which relationships are created, extended and maintained. Scholars view communication, as the meaningful exchange of ideas, information, signals or messages through appropriate channels, enabling individuals or groups to persuade, seek information and give information based on understanding [1], [2], [3].

As a process, it is an on-going, interactive and continuous activity involving the transmission of thoughts, imparting and sharing of information, conveying and receiving of ideas, data, facts, attitudes and feelings through various forms [4]. Communication satisfies an undeniable need in the society for information. It is an essential strategic management approach for concretising ideas.

Communication within universities is vital for the sustenance of peace, harmony, understanding and countering of rumours, amongst others [4], [5]. No teaching and learning can take place in chaos. The interest groups within the university need to be informed and coordinated in order for universities to enjoy maximum job output as statutorily required. Thus, communication should be a bridge of meaning involving a systematic and continuous process of telling, listening and understanding between the management and the universities' publics [6].

Effective communication in universities could enhance excellent academic performance and proper information processing for the overall benefits of its publics [3]. Meaningful communication informs and educates stakeholders at all levels in an institution and motivates them to support that institution.

As an open and complex system, much interaction occurs within a university environment. Within this system, other complex inputs that cannot be assessed or controlled without communication such as people, ideas, tangible resources, and many others exist. Corporate communication in whatever form is communication within universities.

Corporate communication is a management function that offers a framework for the effective coordination of all internal and external communication with the overall purpose of establishing and maintaining favorable reputations with stakeholder groups upon which the organization is dependent [15], [16]. It provides a link between key issues facing an organisation and the organisation's communication plans [18]. Corporate communication is a specialized public relations tactic to developing a centralised internal and external communication aimed at creating and maintaining favourable relationships between an organisation and its stakeholders [15], [19].

Organisations mostly employ corporate communication to gain competitive advantage through the promotion of positive image in their interactions with their stakeholders. Corporate communication coordinates and integrates all communication emanating from an institution to achieve an excellent corporate image for that institution [19], [33], [34]. Most of which are packaged by the communication officer based on how the office is labelled in each university [13], [14].

Universities are not just businesses; they are much more. They have values, expertise, a long history and tradition of molding destinies. The success of what university administrators do depends on how effective their communication is, with their various publics within and outside the university environment [20], [31]. Corporate communication helps universities to promote their image and defend their reputation. It assists universities in adapting to their environment by achieving a balance between commercial imperatives and socially acceptable organizational behaviour [21], [32].

Effective corporate communication helps universities to identify and manage known and unknown crisis; create and maintain favourable relationships with their stakeholders through communication [8]. Likewise, it helps to mobilise university staff and students; thereby ensuring that university goals, initiatives, messages and values are understood and shared by the education community.

Furthermore, corporate communication is an essential asset to universities because it could help to counter annoying hiccups caused by noise in the communication process. How an organization or institution responds when its objectives and communication are miscommunicated or misunderstood could mean the difference between a swift resolution and outright stagnation fueled by a crisis [17]. Some fractures of corporate communication for Nigerian universities include strikes, protests, riots and rumours.

Corporate communication strategy is both internal and external, long-term focused and sometimes, short-termed but most importantly, pro- 
active which makes it a flexible tool of effectiveness for universities [17]. Proper organisation of communication practitioners and functional areas within universities determine, to a large extent, the level of corporate communication activation in universities [8]. Whether the communication function is enabled to provide strategic input to decisionmaking at management level or not, communication activities carried out at various places within the institution will be streamlined and coordinated. In other words, the organisation of corporate communication has essential, strategic and political dimensions; and it is crucial adequate support and integration of all communication activities.

The labelling of corporate communication units in Nigerian universities differs in each university as seen from the pre-test. There is no standardised way of naming corporate communication unit to be different and distinguish its functions from those of other units within the university.

The educational regulatory agency in Nigeria, the National Universities Commission (NUC), basically ensures accreditation and the delivery of quality university education. Nothing in its goals talks about how universities should christen their communication office [22], which means that individual universities design their own communication offices and christen it, perhaps based on their individual communication needs.

Communication officers manage communication processes in universities [7]. These officers provide the human face to communication aimed at attracting the goodwill of the university's various publics. Also, higher institutions of learning engage communication officers to direct, control and structure the communication process. Part of universities' investments in communication is to provide a communication unit, which supervise communication activities internally. These units are identified in each university by their activities, functions, roles of its officers, structure, location, specialization of its officers among others [8]. Most, if not all of these attributes could be telescoped into a single morpheme, name [9].

Names are rich sources of information. They are vehicles for speaking and thinking about objects in a direct, yet, expressive fashion [9]. They mirror the characteristic and attributes of a person, place or objects. Naming an individual or an object underscores a level of significance to that person or object. There are different kinds of names; however, the paper catalogues them into two broad categories: descriptive and proper names. Descriptive names are expressive. They provoke the imagination and usually have some level of information for the hearer. An example is the name of the corporate communication unit of the Lagos State University (LASU) - Centre for Information, Press and Public Relations (CIPPR). This name embodies in it some of the functions of the Unit. On the other hand, people and places get proper names. For example, there are names for cities, countries, parks, mountains, rivers, planets, universities, churches, organisations, restaurants, animals, artifacts, events, ideas and theories.

Names are essential parts of the university brand and its image. It is the anchor for its positioning. Names are not only an indispensable means of identification; it portrays that whatever is named exists. An ancient Egyptian proverb says that names and essence are interconnected [23].

Therefore, the proper situation and labelling of communication units in universities are important. It distinguishes and identifies the Unit, describes its functions and in some cases, its location - for instance, the Directorate of Media and Corporate Affairs, Office of the Vice Chancellor, Covenant University. Also, adequate naming of a corporate communications unit provides focus and direction to its operations as well as all of the university's messages and interaction [13], [14].

Universities around the world create corporate communication units to manage their communication and propagate their missions [24], [25], [30]. This Unit play an important part in how employees, investors and the general public see a university. They create an avenue for effective communication between managers and stakeholders of the institution. Often, these offices' several responsibilities aid in the advancement of the objectives of the university to enhance its corporate image [25], [26]. However, their functions and operations vary from one university to another, mainly because of differences in vision, mission, goals and values.

Covenant University's Media and Corporate Affairs Directorate is the official communication window of the University to its various publics. The Directorate is responsible for news gathering, writing and dissemination. It plays a utility function in creating design solutions that have a high visual and communication impact in promoting the corporate goal of the University as well as managing technical 
services during University events. The Directorate is also responsible for protocol and event services; media relations and publicity for the establishment and maintenance of an excellent interface with local, national, and international news media [27].

The information unit in the University of Ilorin is called the Directorate of Corporate Affairs. The Directorate is charged with the following functions:

...managing the corporate communication of the University by designing effective communication strategies and marshalling effective tools for their execution. Its major mandate is to project the image of the University positively among its internal and external public...it also advises the ViceChancellor on strategic engagement with the mass media; coordinates public communication campaigns and events; maintains steady presence and positive projection of the University in the mass media; monitor public communication process and provide fresh information to the public on the activities of the University as well as give occasional clarifications on issues as they relate to the University...the Directorate currently serves as secretariat to some key committees of the University [28].

At the University of Rwanda, the Unit's name is Corporate Communications Unit with the following stipulated functions:

The Corporate Communication Unit is responsible for coordinating all communication activities in the university. In this regard, the Corporate Communications Unit must support and coordinate all communication efforts with the main aim of enabling the Vice Chancellor or designated spokesperson to perform all functions as chief communicator of the University. The Unit shall provide strategic advice and counsel with regard to communication policy development, develop and implement communication plans and produce publications for information dissemination [29].

The Public Affairs Directorate at the University of Ghana is primarily responsible for planning, organising and managing programmes and activities which enhance the flow of communication between the University and its publics. Specifically, the Directorate handles public relations, media relations, publications, supervisory roles, protocol, tourism and others.

On the website of the National Universities Commission, the communication unit is Public Affairs. Although the Director's profile still reflects the old nomenclature, Department of Corporate Communications. Unfortunately, the mandate and functions of the department were not listed nor do the goals and functions of the institution capture what the functions of corporate communication units should be [22], which means that determining the functions of a communication unit is the sole responsibility of universities.

This situation accounts for the reasons most communication units of universities are not even on the university's website. Universities that include it on their website, leave the page blank. Some have the picture of the head of the Unit while every other information shows - coming soon.

From the preceding, a fact that is certain across the board is that all the communication units manage information, image and media of their institutions. However, the way the units execute these functions may differ. Corporate communication functions cover all the communication activities in a university as expressed by the selected institutions. The job of the corporate communication units therefore, is to provide creative and persuasive solutions to achieving these set functions of the university.

\section{Problem Formulation}

Over the years, an increasing body of literature points to the importance of naming [9], [7], [10]. According to the authors, naming is important because it speaks to a person or an organisation's identity. Although, identity could be a complicated concept when examined in a philosophical context [11]. However, a name could capture many of the attributes of identity [9].

As a unit that mirrors the entire university, the name of a communication unit is significant. Names are a rich source of information. It can tell the activity, role, location, structure, practice and functions of a communication unit. However, the scenario in Nigerian universities is one of confusion as communication units are named based on what the university expects from the unit rather than professional description of the unit. The danger in this is that a communication unit that is named, for 
instance, marketing and communication unit, may not know what is expected of it when crisis occur in the university.

Just as the name of a communication unit has strategic implications, the functions of that unit distinguish it from other units within the university. Depending on the expectation of a university, the functions of its communication unit varies [12]. Some university's communication units handle dissemination of information within the university and relate with the press, and others extend into community relations while others comprise the printing press [13], [14]. In some cases, different units with different names handle each of these functions; which leads to the question concerning what the exact function of a communication unit is within a university.

Additionally, as citadels of learning, universities teach the best practices of communication [3]. In practice, they should not lag behind be pacesetters. Thus, this study aims to uncover the various terms of corporate communication units within universities. It will also reveal their functions and influence within the universities.

Based on the peculiarities of the study, the respondents were employees of corporate communication units and faculty members of mass communication department of six selected universities in southwest, Nigeria. The states used for the study were Lagos, Ogun and Oyo States. Two universities, one public and one private were selected from each state. They include Lagos State University and Caleb University, Lagos; Federal University of Agriculture, Abeokuta, Ogun State and Babcock University, Ogun State; as well as University of Ibadan, Oyo State and Lead City University, Ibadan, Oyo State.

Therefore, to provide empirical responses to this study, the mixed method approach was adopted. Specifically, In-depth interview was used to garner detailed information from the communication officers on the nomenclature of their Units, its functions and the influence of the name on how the Units operates. While, descriptive survey was used in uncovering employees' knowledge of the same subject matter. Thus, a total of one hundred and fifty copies of questionnaire were administered to employees of corporate communication units and faculty members of mass communication. Purposive sampling was used in the selection of the communication officers.
Census method was used for the employees because both corporate communication units and mass communication department employees were few. These groups of employees were selected because communication officers relate and communicate on behalf of the university and with the help of other employees in the Unit, they also execute and coordinate all the corporate communication decisions for their universities [35].

Seen as experts, mass communication faculty members remain recognised. The recorded interviews were transcribed and examined. The constant comparative technique provided responses grouped according to themes, patterns, similarities and differences for each university. Furthermore, the survey's cross-tabulations identified the patterns of relationship between variables.

\section{Problem Solution}

Out of 150 copies of the questionnaire administered among the employees of corporate communication units and mass communication faculty members of six selected universities, only 121 representing $80.7 \%$ usable copies of questionnaire were returned from all the universities.

Table 1. Gender of Employees

\begin{tabular}{|c|c|c|c|c|c|c|c|}
\hline & \multicolumn{6}{|c|}{ Universities } & \multirow[b]{2}{*}{$\begin{array}{l}\text { Total } \\
(\%)\end{array}$} \\
\hline & $\begin{array}{l}\text { LAS } \\
\text { U }\end{array}$ & $\begin{array}{l}\text { CALE } \\
\text { B }\end{array}$ & $\begin{array}{l}\text { FUNAA } \\
\text { B }\end{array}$ & $\begin{array}{l}\text { BAB- } \\
\text { COC } \\
\text { K }\end{array}$ & UI & $\begin{array}{l}\text { LEA } \\
\text { D } \\
\text { CITY }\end{array}$ & \\
\hline Male & 73.2 & 66.7 & 77.8 & 52.0 & $\begin{array}{l}56 . \\
5\end{array}$ & 85.7 & 66.9 \\
\hline $\begin{array}{l}\text { Femal } \\
\mathrm{e}\end{array}$ & 26.8 & 33.3 & 22.2 & 48.0 & $\begin{array}{l}43 . \\
5\end{array}$ & 14.3 & 33.1 \\
\hline Total & 100 & 100 & 100 & 100 & 100 & 100 & $\begin{array}{l}100 \\
n=12 \\
1\end{array}$ \\
\hline
\end{tabular}

Employees of corporate communication units and faculty members of mass communication department were selected respondents for this study. Therefore, the gender distribution of employee respondents from the two departments of the six selected universities as presented in Table 1 shows that majority of the respondents, $66.9 \%$ were males and more than a quarter $(33.1 \%)$ were females. 
As an aside, United Nations' Sustainable Development Goal 5 on gender equality needs more attention in the universities, considering the gender imbalance that was discovered in this instance.

Table 2. Distribution of Employees

\begin{tabular}{|c|c|c|c|c|c|c|c|}
\hline & \multicolumn{6}{|c|}{ Universities } & \multirow[b]{2}{*}{$\begin{array}{l}\text { Total } \\
(\%)\end{array}$} \\
\hline & LASU & CALEB & FUNAAB & $\begin{array}{l}\text { BAB- } \\
\text { COCK }\end{array}$ & UI & $\begin{array}{l}\text { LEAD } \\
\text { CITY }\end{array}$ & \\
\hline $\begin{array}{l}\text { Mass } \\
\text { Comm }\end{array}$ & 46.3 & 100 & 0 & 52.0 & 34.8 & 71.4 & 49.6 \\
\hline $\begin{array}{l}\text { Comm } \\
\text { Unit }\end{array}$ & 53.7 & 0 & 100 & 48.0 & 65.2 & 28.6 & $\begin{array}{l}50.4 \\
\end{array}$ \\
\hline Total & 100 & 100 & 100 & 100 & 100 & 100 & $\begin{array}{l}100 \\
n=121\end{array}$ \\
\hline
\end{tabular}

Table 2 shows that the corporate communication unit employees are a little more than mass communication faculty members in most universities. FUNAAB however, has zero units because the university disallowed consent to survey the faculty members and the employees of the corporate communication unit of Caleb University.

Table 3. Years of Service of Employees

\begin{tabular}{|l|l|l|l|l|l|l|l|}
\hline \multirow{2}{*}{} & \multicolumn{5}{|c|}{ Universities } & \multirow{2}{*}{$\begin{array}{l}\text { Total } \\
(\%)\end{array}$} \\
\cline { 2 - 8 } & LASU & CALEB & FUNAAB & $\begin{array}{l}\text { BAB- } \\
\text { COCK }\end{array}$ & UI & $\begin{array}{l}\text { LEAD } \\
\text { CITY }\end{array}$ & \\
\hline $\begin{array}{l}\text { Less } \\
\text { than a } \\
\text { Year }\end{array}$ & 9.8 & 0 & 11.1 & 12.0 & 4.3 & 7.1 & $\mathbf{8 . 3}$ \\
\hline $\begin{array}{l}1-3 \\
\text { years }\end{array}$ & 4.9 & 66.7 & 22.2 & 32.0 & 21.7 & 28.6 & $\mathbf{2 2 . 3}$ \\
\hline $\begin{array}{l}4-6 \\
\text { years }\end{array}$ & 17.1 & 11.1 & 0 & 28.0 & 26.1 & 28.6 & $\mathbf{2 0 . 7}$ \\
\hline $\begin{array}{l}7-9 \\
\text { years }\end{array}$ & 29.3 & 22.2 & 33.3 & 24.0 & 13.0 & 14.3 & $\mathbf{2 3 . 1}$ \\
\hline $\begin{array}{l}10 \text { and } \\
\text { Above }\end{array}$ & 39.0 & 0 & 33.3 & 4.0 & 34.8 & 21.4 & $\mathbf{2 5 . 6}$ \\
\hline \begin{tabular}{l} 
Total \\
\hline
\end{tabular} & 100 & 100 & 100 & 100 & 100 & 100 & $\begin{array}{l}\mathbf{1 0 0} \\
\mathbf{n = 1 2 1}\end{array}$ \\
\hline
\end{tabular}

The three selected public universities as shown in Table 3 have existed for a long time, thereby, having long-service staff on their payroll. However, it is interesting to also see Lead City University, a younger university scoring $21.4 \%$ of long-serving staff.
The years of service reveals that most of the respondents have been in the university long enough to witness the establishment of some of the communication units which includes the naming and modus operandi.

Table 4. The name of the Corporate Communication Unit

\begin{tabular}{|c|c|c|c|c|c|c|c|}
\hline \multirow{2}{*}{ Unit Names } & \multicolumn{6}{|c|}{ Universities } & \multirow{2}{*}{$\begin{array}{l}\text { Total } \\
(\%)\end{array}$} \\
\hline & LASU & CALEB & FUNAAB & $\begin{array}{l}\text { BAB- } \\
\text { COCK }\end{array}$ & UI & $\begin{array}{l}\text { LEAD } \\
\text { CITY }\end{array}$ & \\
\hline $\begin{array}{l}\text { Media and } \\
\text { Public } \\
\text { Relations Unit }\end{array}$ & 0 & 22.2 & 0 & 12.0 & 4.3 & 0 & 5.0 \\
\hline $\begin{array}{l}\text { Directorate of } \\
\text { Corporate and } \\
\text { Students' } \\
\text { Affair }\end{array}$ & 0 & 0 & 0 & 0 & 0 & 0 & 0 \\
\hline $\begin{array}{l}\text { Directorate of } \\
\text { Public } \\
\text { Communication }\end{array}$ & 0 & 0 & 0 & 0 & 69.6 & 0 & 13.2 \\
\hline $\begin{array}{l}\text { Centre for } \\
\text { Information, } \\
\text { Press and } \\
\text { Public } \\
\text { Relations } \\
\end{array}$ & 85.4 & 0 & 0 & 0 & 0 & 0 & 28.9 \\
\hline $\begin{array}{ll}\text { Directorate of } \\
\text { Public } \\
\text { Relations } \\
\end{array}$ & 0 & 0 & 55.6 & 0 & 0 & 0 & 4.1 \\
\hline $\begin{array}{l}\text { Department of } \\
\text { Marketing and } \\
\text { Communication }\end{array}$ & 0 & 0 & 0 & 36.0 & 0 & 0 & 7.4 \\
\hline Other & 14.6 & 77.8 & 44.4 & 52.0 & 26.1 & 100 & 41.4 \\
\hline Total & 100 & 100 & 100 & 100 & 100 & 100 & $\begin{array}{r}100 \\
n=121\end{array}$ \\
\hline
\end{tabular}

Accordingly, Table 4 shows the labels of corporate communication units in each of the selected university. These names were confirmed directly from the heads of the Unit.

The Table shows that majority, $85.4 \%$, of LASU's employees, know the name of their communication's Unit. Closely following in this flow of knowledge is University of Ibadan scoring, 69.6\% and FUNAAB came in next with $55.6 \%$, which is only a little above half of its respondents. All these universities are longstanding universities, leading to the assumption that their longevity would aid their respondents' memorability.

On the other hand, the privately owned universities performed differently, as most of the employees do not know the specific names of their corporate communication units. At the top is Lead 
City University, where a $100 \%$ of the employees including the staff members of the Communication Unit were not sure of the name of the Unit. Some employees wrote down the name of the head of the Unit as the name of the Unit, others left the space blank, while a few kept referring to it as Corporate Affairs.

Caleb University employees were not excluded from the bandwagon as majority of the respondents, $77.8 \%$, mostly referred to their communication unit as Public Relations Unit. Generally, all the six selected universities towed the same line of mixed name-calling or usage of completely different names to refer to their corporate communication unit.

\subsection{Report of in-depth interview}

An obvious observation was that communication officers, unlike other employees, were certain of the name of the Unit they were heading. Correspondingly, Lagos State University calls it Centre for Information, Press and Public Relations (CIPPR), Caleb University calls its own, Media and Public Relations Unit. At the same time, the Federal University of Agriculture Abeokuta has a Directorate of Public Relations. In a related development, in Babcock University, the Unit is called Department of Marketing and Communication. In University of Ibadan, it is known as Directorate of Public Communication while at Lead City University, the corporate communication unit is called Directorate of Corporate and Students' Affairs.

The communication officers also listed a number of the Unit's function to include communication management, public relations, participation in the strategic planning processes of university's administration, counseling of management, planning of events, serving as masters of ceremony, protocol/guest reception, marketing, printing of various university publications, web-designing, crisis management and external communication coordination. However, the officers also noted that some of the functions were handled by other units in the university. In some cases, they get to supervise or work with a unit handling a particular function while in some other, they do not. Invariably, all the communication officers believed they were primarily public relations and communication managers.

To ascertain whether the name of the communication unit influenced how communication units operate, the six communication officers explained that this varied. For instance, Lead City
University claimed that bonding the corporate communication unit with student affairs had made information dissemination, particularly, to the students easier for the university and the added responsibility has not detracted from the tasks of the Unit. Comparing this claim with the result in Table 4, where a $100 \%$ of the employees were not sure of the name of their communication's Unit including the staff members of the communication unit, it is evident that there is a lacuna.

Babcock University also noted that the name of their communication unit does not limit their operations. However, it has helped to define tasks of the Unit. Further explanation shows that the Communication Unit handled everything marketing, promotion, communication and reputation-wise. Although some newly-created units now handle other communication functions such as community relations and others.

The officers also listed other factors that served as influencers. First was the redistribution of some of the communication unit's functions to other units within the university to handle. Rather than, creating a directorate that encapsulates all the functions of a corporate communication unit, universities disintegrate the Unit with the notion that they are making work easier for the Unit. The second was inadequate and rotation of staff which does not allow for growth, expertise, consistency and commitment to the job.

The officers also noted that some of their functions were redundant because they did not have professionals to handle them. Also, management could change heads of corporate communication at will, and a change of the head could mean a change in the name, functions and operations of the Unit.

The data presented indicate that corporate communication units are christened differently by respective universities. Also, $41.4 \%$ of the respondents do not know the names of their communication units. Another observation is that the names of corporate communication units influences how the unit operates as can be seen in the case of Lead City University, Babcock University and others.

It is also possible that splitting up some of the communication unit's functions to other units within the university to handle could affect how the unit is named and thus, function.

The study suggests that universities could adopt the Directorate style that encapsulates all of their 
functions as a corporate communication unit. Possibly, universities could adopt Directorate of Public Relations as the general name of corporate communication units since there is no standardised manual for universities to use. This name is easy for all university community members to remember. The name also embodies the normal functions of the Directorate and as such, university management would be mindful of disintegrating the functions of the Directorate. The management would be careful to employ professionals, and the communication unit would be able to operate more as a management function.

\section{Conclusion}

As the names of the corporate communication units are, so are their functions. Most of the universities' communication units focus more on media if their name suggests it. Some have marketing and promotion as their anchor while others tilt towards production, protocol and events as a total corporate affairs package. However, corporate communication embodies more than this because of its connection to public relations.

Also, by naming a communication unit Directorate of Corporate Communication and having public relations as one of its functions contradicts what universities teach in the classroom which shows corporate communication as a branch or one of the functions of public relations. Given that the National Universities Communication (NUC) has no guide on how universities should name their corporate communication units and the various functions expected of them. Meaning that universities decide on how to label their communication units and dictate the functions the units should assume.

The study, therefore, recommends that universities could adopt Directorate of Public Relations for uniformity.

\subsection{Acknowledgement}

We like to acknowledge Covenant University, Ota, Ogun State, Nigeria for sponsoring the publication of the paper.

\section{References}

[1] Coates, G. T., Notes on communication: A few thoughts about the way we interact with the people we meet, 2009. Retrieved from http://www.wanterfall.com/Downloads/Com munication.pdf
[2] Velentzas, J. \& Broni, G., Communication cycle: Definition, process, models and examples. Recent Advances in Financial Planning and Product Development, 2014, pp. 117-131. Retrieved from http://www.wseas.us/elibrary/conferences/2014/Istanbul/FINANCE /FINANCE-17.pdf

[3] Johnson, S., Veitch, S. \& Dewiyanti, S., A framework to embed communication skills across the curriculum: A design-based research approach. Journal of University Teaching and Learning Practices, Vol.12, No.4, 2015, pp. 1-16.

[4] Howard, M., Effective communication in higher education, 2014. Retrieved from https://files.eric.ed.gov/fulltext/ED547634.pd $\mathrm{f}$

[5] Iordache-Platis, M. \& Josan, I., Communication Efficiency within Higher Education Institutions: The Case of Romania. European Research Studies, Vol.XII, No.2, 2009, pp. 55-66.

[6] Lunenburg, F. C., Communication: The process, barriers, and improving effectiveness. Schooling, Vol.1, No.1, 2010, pp. 1-11.

[7] University of Greenwich, Job description: $P R$ and internal communications officer, 2017. Retrieved from https://jobs.gre.ac.uk/Upload/vacancies/files/ 3868/Internal\%20Comms\%20Officer.pdf

[8] Ekanem, T., Olatunji, R., Amodu, L., Odiboh, O. \& Oyero, O., Use of indigenous language in community relations: A conceptual analysis of corporate communication practice by Nigerian universities. In Kehinde, O. \& Abiodun, S. (eds). Emerging Trends in Indigenous Language Media, Communication, Gender and Health, IGIGLOBAL, 2020, pp. 242-262.

[9] Jeshion, R., The significance of names. Mind \& Language, Vol.24, No.4, 2009, pp. 370-403.

[10] Uslu, B. (2017). The components of communication systems in universities: their influence on academic work life. Journal of Tertiary Education and Management, Vol.24, No.1, 2017, pp. 34-48.

[11] Ekanem, T., Understanding five tools of Philosophy. In Oscar, O., Abiodun, S. \& Chris, D. (Eds.). Introduction to philosophy of mass communication for higher 
institutions. Stirling-Horden Publishers Ltd., 2019.

[12] Gorkemli, N. H. \& Cetinkaya, B., Corporate communication units' functions in strategic planning: Case of Kayseri's top industrial companies. The Turkish Online Journal of Design, Art and Communication - TOJDAC, Vol.7, No.4, 2017, pp. 566-575.

[13] University of Nairobi, Communication policy. 2014. Retrieved from http://cessp.uonbi.ac.ke/sites/default/files/ces sp/UoN_Communication_Policy.pdf

[14] University of Waterloo, Media relations: Engaging with the media guide. 2014. Retrieved from https:/uwaterloo.ca/universitycommunications/sites/ca.universitycommunications/files/uploads/files/c005519 mediaguide_may2014_create_accessible_fin al-s.pdf

[15] Fashiku, C. O., Communication issues and challenges in Nigeria university system. American Journal of Language and Literacy, Vol.1, No2, 2016, pp. B1-B9.

[16] Cornelissen, J. P., Corporate communication: A guide to theory and practice, $5^{\text {th }}$ edition. Sage Publications, 2017.

[17] Argenti, P. \& Forman, J., The power of corporate communication: Crafting the voice and image of your business. McGraw-Hill, 2002.

[18] Olatunji, R. W., As other see us: Differing perceptions of public relations in Nigeria among practitioners and general public. Public Relations Review, 2014, pp. 466-472.

[19] Steyn, B., From strategy to corporate communication strategy: A conceptualization. Journal of Communication Management, Vol.8, No.2, 2004, pp. 168-183.

[20] Ekanem, T., Olatunji, R., Amodu, L., Odiboh, O., Yartey, D., Adesina, E. \& Adeyeye, B., A Case for e-Teaching and e-Learning of Destination Public Relations in Nigeria. Proceedings of the 31st International Business Information Management Association Conference (IBIMA), Milan, 2018.

[21] Amodu, L., Odiboh, O., Usaini, S., Yartey, D., \& Ekanem, T., Data on Security Implications of the Adoption of Internet of Things by
Public Relations Professionals. Data in Brief 27:104663, 2019. DOI: 10.1016/j.dib.2019.104663.

[22] National Universities Commission, Pubic Affairs 2020. Retrieved from https://www.nuc.edu.ng/project/publicaffairs/

[23] Vittmann, G. (2013). Personal names: Function and significance. UCLA Encyclopedia of Egyptology, Vol.1, No.1, 2013, pp.1-13.

[24] Frederick, A., What are the functions of a corporate communication department? 2019. Retrieved from https://smallbusiness.chron.com/functionscorporate-communication-department23716.html

[25] Aikins, E. D \& Adu-Oppong. A. A, Using Public Relations as a Management Tool in Tertiary Institutions. Afro Asian Journal of Social Sciences, Vol.VI, No.2, 2015, pp. 115.

[26] Almudallal, M. W. \& Bakri, N., Examining the Role of Public Relations Departments in Universities and their Relationships with the Graduates in Palestine. Journal of Business and Social Review in Emerging Economies, Vol.3, No.1, 2017, pp. 101-109.

[27] Covenant University, Media and Corporate Affairs Directorate 2019. Retrieved from https://covenantuniversity.edu.ng/AboutUs/Media-and-Corporate-AffairsDirectorate\#.XnCkzahKjIU

[28] University of Ilorin, Directorate of Corporate Affairs, 2020. Retrieved from http://www.unilorin.edu.ng/index.php/inform ation

[29] University of Rwanda, Communication policy, 2017. Retrieved from https://ur.ac.rw/documents/UR\%20Communi cation\%20Policy.pdf

[30] Bloom, L., The Role of the Communication Department in an Organization, 2018. Retrieved from https://bizfluent.com/info8673875-role-communication-departmentorganization.html

[31] Workman, C., Laporte, N. \& Elliot, D. E., Guide to communications in a university context, $2015 . \quad$ Retrieved from https://www.caubo.ca/wpcontent/uploads/2016/02/CAUBO_CUC_Gui de_20150630.pdf 
[32] Goodman, M. B., Corporate communication practice and pedagogy at the dawn of the new millennium. Corporate Communications: An International Journal, Vol.1, No.3, 2006, pp. 196-213.

[33] Odiboh, O. O., Marketology: A Philosophy of marketing communication for students, teachers and professionals, Second Edition, Babcock University Press, 2020a.

[34] Odiboh, O. O. Integrated marketing communication in Nigeria, Advertising
Practitioners Council of Nigeria (APCON), 2020b.

[35] Mamuli, L. C., Mutsotso, S. N. \& Namasaka, D. B., The Influence of Communication Channels on Management Practices in Kenyan Public Universities. International Journal of Academic Research in Progressive Education and Development, Vol.2, No.1, 2013, pp. 257-267.

\section{Creative Commons Attribution License 4.0} (Attribution 4.0 International, CC BY 4.0)

This article is published under the terms of the Creative Commons Attribution License 4.0

https://creativecommons.org/licenses/by/4.0/deed.en_US 